\title{
Kesesuaian teori perkembangan kognitif piaget pada peserta didik kelas I dan II dalam memahami hukum kekekalan
}

\author{
Faridatul Wardi ${ }^{1}$, Laila Hayati ${ }^{2}$, Nani Kurniati ${ }^{3}$, Sripatmi $^{4}$ \\ ${ }^{1}$ Mahasiswa Prodi Pendidikan Matematika, FKIP Universitas Mataram \\ 2,3,4Dosen Prodi Pendidikan Matematika, FKIP Universitas Mataram \\ Email: faridatulwardi@gmail.com \\ Diterima:20-09-2021; Direvisi:26-09-2021; Dipublikasi:30-09-2021
}

\begin{abstract}
This study aims to determine the suitability of cognitive development of class I and II students in understanding the law of conservation of numbers, conservation of material and long conservation with Jean Piaget's theory of cognitive development. This type of research is quantitative with a qualitativedescriptive approach. This study population was 52 students in grades I and II Academic Year 2020/2021 with a sampling technique using a purposive sampling technique. Based on this technique, 14 research samples were obtained, six samples from class I and eight samples from class II. The instrument used was a test in the form of a brief description of the law of conservation of numbers, conservation of matter and conservation of length. The non-test instrument is an interview combined with a simple experiment. Interviews and simple experiments in this study use coins to the conservation of numbers, water and glass for the conservation of matter, and finally the rope for the conservation of length. Based on the results of the data analysis on the answers to the students' test questions, it is known that $50 \%$ of students already understand the law of conservation of numbers, the law of conservation of matter and the law of long conservation. Meanwhile, based on the results of interviews and simple experiments, it is known that 7 students have understood the law of conservation of numbers, conservation of matter and conservation of long, 2 students have understood the law of conservation of numbers and conservation of matter, 2 students have understood the law of conservation of numbers and conservation of length, 2 participants students understand the law of the conservation of numbers and 1 student who does not understand the three conservation laws. For further researchers, they can research the causes of students who have entered the concrete thinking stage and do not understand the law of eternity.
\end{abstract}

Keywords: Jean Piaget's Cognitive Theory, Conservation of Numbers, Conservation of Matter, Law of Conservation of Length

\begin{abstract}
Abstrak
Penelitian ini bertujuan untuk mengetahui kesesuaian perkembangan kognitif peserta didik kelas I dan II dalam memahami hukum kekekalan bilangan, kekekalan materi dan kekekalan panjang sesuai dengan teori perkembangan kognitif Jean Piaget. Jenis penelitian ini adalah kuantitatif dengan pendekatan kualitatif-deskriptif. Populasi penelitian ini adalah seluruh peserta didik kelas I dan II Ajaran 2020/2021 sebanyak 52 peserta didik dengan teknik pengambilan sampel menggunakan teknik purposive sampling. Berdasarkan teknik tersebut didapatkan 14 sampel penelitian. 6 sampel dari kelas I dan 8 sampel dari kelas II. Instrumen yang digunakan adalah tes berupa uraian singkat tentang hukum kekekalan bilangan, kekekalan materi dan kekekalan panjang. Adapun instrumen non-test berupa wawancara yang dipadukan dengan percobaan sederhana. Wawancara dan percobaan sederhana dalam penelitian ini memanfaatkan uang logam uang untuk kekekalan bilangan, air dan gelas untuk kekekalan materi dan terakhir tali untuk kekekalan panjang. Berdasarkan hasil analisis data jawaban soal tes peserta didik, diketahui sebanyak 50\% peserta didik sudah memahami hukum kekekalan bilangan, hukum kekekalan materi dan hukum kekekalan panjang. Sedangkan berdasarkan hasil wawancara dan percobaan sederhana diketahui ada 7 peserta didik sudah memahami hukum kekekalan
\end{abstract}


bilangan, kekekalan materi dan kekekalan panjang, 2 peserta didik sudah memahami hukum kekekalan bilangan dan kekekalan materi, 2 peserta didik sudah memahami hukum kekekalan bilangan dan kekekalan panjang, 2 peserta didik memahami hukum kekekalan bilangan dan 1 peserta didik yang belum memahami ketiga hukum kekekalan. Untuk peneliti selanjutnya bisa melakukan penelitian lanjutan mengenai penyebab peserta didik yang sudah memasuki tahap berpikir konkret belum mampu memahami hukum kekekalan.

Kata kunci: Teori Kognitif Jean Piaget, Hukum Kekekalan Bilangan, Hukum Kekekalan Materi, Hukum Kekekelan Panjang

\section{PENDAHULUAN}

Kurikulum 2013 merupakan suatu kebijakan baru pemerintah Indonesia dalam bidang pendidikan yang diharapkan mampu menjawab tantangan dan persoalan yang akan dihadapi oleh bangsa Indonesia kedepan. Kurikulum 2013 mengharapkan peserta didik memiliki keterampilan afektif, keterampilan koginitf dan keterampilan psikomotorik (Kemendikbud, 2014). Kurikulum 2013 menekankan bagaimana peserta didik tidak hanya mampu mengembangkan keterampilan afektif dan psikomotornya saja tetapi juga dapat mengembangkan keterampilan kognitifnya.

Perkembangan kognitif merupakan salah satu pusat perhatian pendidikan matematika dan sains. Untuk mewujudkan perkembangan kognitif yang baik terhadap peserta didik perlu dilakukan kajian-kajian dan penelitian-penelitian guna memperoleh data bagaimana mewujudkan perkembangan kognitif yang baik. Salah satu cara yang biasa digunakan yaitu dengan mengkaji teori-teori perkembangan kognitif yang telah ada. Salah satu teori yang sering digunakan dalam membahas teori perkembangan kognitif yaitu teori yang dikembangkan oleh Jean Piaget seorang psikolog yang juga ahli biologi kelahiran Swiss pada tahun 1896 (Aini \& Hidayati, 2017). Perkembangan kognitif peserta didik merupakan hal dasar yang penting untuk diketahui, sehingga nantinya guru atau pendidik dapat menyusun materi pembelajaran matematika dan menggunakan model pembelajaran yang sesuai dengan kondisi kognitif peserta didiknya.

Teori perkembangan kognitif Piaget sangat banyak mempengaruhi bidang pendidikan, terlebih pendidikan kognitif. Tahap-tahap pemikiran Piaget sudah cukup lama mempengaruhi bagaimana para pendidik menyusun kurikulum, memilih metode pengajaran dan juga memilih bahan bagi pendidikan anak, terlebih pendidikan di sekolah. Teori kontruktivisme Piaget sangat mempengaruhi bagaimana sebaiknya seorang guru membantu murid membangun suatu pengetahuan. Teori kontruktivisme mempertanyakan apa dan bagaimana peran guru yang baik dan peran murid yang sesungguhnya dalam menggeluti ilmu pengetahuan. Tidak ketinggalan, metode penelitian Piaget banyak mewarnai penelitian pemikiran anak (Aini \& Hidayati, 2017).

Menurut Piaget (Santrok, 2007) pengertian dan pemahaman seseorang itu mengalami perkembangan dari lahir sampai menjadi dewasa. Berdasarkan observasinya, Piaget meyakini bahwa perkembangan kognitif terjadi dalam empat tahapan. Masing-masing tahapan berhubungan dengan usia dan tersusun dari jalan pikiran yang berbeda-beda. Tahap pertama dalam perkembangan kognitif menurut 
Piaget adalah tahap sensorimotor (usia dari kelahiran sampai usia 2 tahun), kedua tahap pra-operasional (usia 2 tahun sampai 7 tahun), ketiga tahap operasional konkret (usia 7 tahun sampai 11 tahun) dan terakhir tahap operasional formal (usia 11 tahun sampai dewasa).

Setiap tahapan perkembangan kognitif mempunyai sifat atau ciri khas masingmasing yang dimunculkan anak yang berbeda-beda. Salah satu ciri yang dimunculkan pada tahap operasi konkret (concrete operational stage) diantaranya yaitu pada tahap ini anak sudah mulai memahami konsep kekekalan. Sebagaimana yang diungkapkan Ruseffendi (2006:147) pada tahap operasi konkret anak mulai memahami konsep kekekalan bilangan (6-7 tahun), konsep kekekalan materi atau zat (7-8 tahun), konsep kekekalan panjang (7-8 tahun), konsep kekekalan luas (8-9 tahun), konsep kekekalan berat (9-10 tahun), bahkan pada akhir tahap ini, anak sudah dapat memahami konsep kekekalan isi (14-15 tahun) (Alhaddad, 2012). Perkembangan kognitif seorang anak menurut Jean Piaget itu tumbuh menurut aturan waktu dan bertahap, serta ditandai dengan kepandaian khusus yang ditunjukkan oleh anak tersebut.

Pandangan Piaget mengatakan bahwa untuk melakukan pengujian kekekalan secara tepat akan tergantung pada tingkatan kognitif atau perkembangan intelektual anak (Orton, 2004). Sebagai contoh kekekalan bilangan, kekalan materi dan kekekalan panjang yang telah disebutkan sebelumnya. Apabila ditinjau dari segi umur dan beberapa penelitian yang pernah dilakukan, ada beberapa anak belum mampu memahami hukum kekekalan ini. Contohnya adalah penelitian yang dilakukan oleh Ramlah (2015) yang mengatakan bahwa ada anak yang sesuai dengan usia tahapan operasi konkret ternyata belum memahami konsep kekekalan materi. Dimana penelitian yang dilakukan oleh Ramlah ini dilakukan di Karawang dan mengambil subjek penelitian sebanyak 3 anak usia 7 tahun, 10 tahun dan 11 tahun. Penelitian lainnya juga dilakukan oleh Alhaddad (2012) yang melaporkan bahwa ada anak yang sesuai dengan usia tahapan operasi konkret ternyata belum memahami konsep kekekalan panjang. Penelitan Alhaddad dilakukan di Kelurahan Geger Kalong, Kecamatan Sukasari Kota Bandung Propinsi Jawa Barat dengan subjek penelitian sebanyak 2 anak umur 8 tahun dan 9 tahun.

Keberagaman usia anak dalam memahami sistem kekekalan, membuat ketertarikan peneliti untuk melakukan percobaan sederhana dan melakukan penelitian yang serupa seperti beberapa penelitian yang telah dilakukan diatas. Percobaan yang dilakukan adalah pengujian terhadap kekekalan bilangan, kekekalan materi dan kekekalan panjang, sedangkan subjek penelitian sebanyak 14 peserta didik kelas I dan II dimana penelitian ini dilakukan di Madrasah Ibtidaiyah Yayasan Al-Mukhtariyah Al-Islamiyah Mamben Daya.

Alasan peneliti melakukan penelitian ini selain berdasarkan urain diatas, di temukan masalah dalam pembelajaran matematika di sekolah, dapat dilihat pada Tabel 1. 
Tabel 1. Nilai UTS Matematika Semester Ganjil Kelas I dan II TP 2020/2021

\begin{tabular}{ccc}
\hline Kelas & Nilai Rata-Rata & Ketuntasan Klasikal (\%) \\
\hline Kelas I & 76 & $61 \%$ \\
Kelas II & 73 & $64 \%$ \\
\hline Sumber: guru & &
\end{tabular}

Dari Tabel 1 dapat dilihat bahwa hasil belajar matematika peserta didik belum mencapai ketuntasan klasikal yaitu masih berada dibawah $85 \%$ dari seluruh peserta didik. Menurut Mufarizuddin (2017) menyatakan bahwa suatu kelas dikatakan tuntas belajarnya (ketuntasan klasikal) jika ketuntasan klasikal peserta didik telah mencapai 85\% dari seluruh peserta didik, maka hasil belajar peserta didik secara klasikal telah tercapai dengan baik. Oleh karena itu, dari Tabel 1 dapat diketahui bahwa nilai hasil belajar matematika kelas I dan II belum tercapai dengan baik atau belum tuntas belajarnya.

Tabel 2. Data Nilai UTS Semester Ganjl Kelas I dan II TP 2020/2021

\begin{tabular}{ccc}
\hline Mata Pelajaran & \multicolumn{2}{c}{ Nilai Rata-Rata } \\
\cline { 2 - 3 } & Kelas I & Kelas II \\
\hline Tematik & 78 & 80 \\
Matematika & 76 & 73 \\
\hline
\end{tabular}

Sumber: guru

Dari Tabel 2 dapat diketahui bahwa mata pelajaran matematika mendapat nilai rata-rata UTS lebih rendah dibandingkan nilai rata-rata mata pelajaran tematik pada kelas I dan II di Madrasah Ibtidaiyah Al-Mukhatriyah Al-Islamiyah Mamben Daya. Menurut Riyatuljannah dan Suyadi (2020) mengatakan bahwa, hubungan antara matematika dengan perkembangan kognitif adalah hal yang signifikan, matematika memberikan dampak berarti bagi berkembangnya kognitif seseorang. Kesiapan anak untuk belajar matematika ditinjau dari kesiapan struktur kognitifnya yaitu kapasitas kemampuan berpikir secara terorganisir dan terkoordinir. Agar dapat memahami materi Matematika dengan baik, maka anak harus sudah siap menerima materi tersebut, artinya anak sudah memiliki hukum kekekalan dari jenjang materi yang dipelajari (Hidayati, 2012)

Berdasarkan hasil wawancara dengan guru wali kelas I dan II tanggal 25-27 Agustus 2020 dan 7 Oktober 2020 didapatkan informasi bahwa peserta didik kelas I dan II rata-rata belum berada dalam tahap memahami konsep hukum kekekalan bilangan, kekekalan materi dan kekekalan panjang. Menurut guru wali kelas hal ini bisa dilihat dari rendahnya nilai matematika peserta didik dibandingkan mata pelajaran yang lain dan juga ketika guru melakukan manipulasi terhadap benda-benda dalam operasi perhitungan sederhana seperti penjumlahan dan pengurangan, peserta didik masih sering keliru dalam menyelesaikan masalah penjumlahan dan pengurangan tersebut yang menggunakan manipulasi benda dalam perhitungan. Selain 
itu, ketika anak dihadapkan dengan wadah yang berisi air yang sama namun dengan wadah yang berbeda peserta didik rata-rata belum bisa menentukan kesamaan banyak air walaupun diletakkan di wadah yang berbeda. Untuk kekekalan panjang sendiri peserta didik masih keliru dalam menyatakan kekekalan panjang suatu tali ketika tali tersebut dirubah bentuknya. Sedangkan berdasarkan teori perkembangan kognitif Piaget seharusnya peserta didik dalam usia ini sudah memahami konsep hukum kekekalan tersebut. Dari hasil wawancara juga didapatkan informasi bahwa guru kelas dari kelas tersebut belum memahami apa itu konsep hukum kekekalan bilangan, kekekalan materi dan kekekalan panjang. Hal ini bisa dilihat dari hasil wawancara ketika peneliti menanyakan tentang hukum kekekalan guru menjelaskan berbeda dari konsep hukum kekekalan yang dikemukakan oleh Jean Piaget dan juga guru menanyakan ulang mengenai definisi hukum kekekalan bilangan, kekekalan materi dan kekekalan panjang. Hal ini tentu sebuah masalah, karena jika guru tidak mengetahui konsep hukum kekekalan, bagaimana guru akan mengetahui perkembangan kognitif peserta didiknya sehingga nantinya bagaimana mungkin guru akan memberikan materi yang sesuai dengan kondisi kognitif yang dimiliki peserta didik tersebut. Sedangkan menurut Funny (2014) dalam hasil penelitiannya menyatakan bahwa, proses pembelajaran matematika akan lebih mudah diikuti anak apabila telah memiliki pemahaman konservasi yang baik. Pemahaman tentang konsep konservasi akan mempermudah anak dalam manipulasi objek matematika. Karena itu penting dilakukan identifikasi terlebih dahulu berkaitan dengan kemampuan konservasi peserta didik sehingga guru akan mempunyai gambaran terhadap kemampuan awal peserta didik. Dengan demikian guru dapat merancang pembelajaran yang tepat sesuai dengan kondisi peserta didik dalam kelas.

Berdasarkan uraian latar belakang di atas, maka peneliti tertarik melakukan penelitian yang berjudul: "Kesesuaian Teori Perkembangan Kognitif Piaget Pada Peserta Didik Kelas I Dan Ii Dalam Memahami Hukum Kekekalan". Penelitian ini memfokuskan pada pemahaman konsep kekekalan bilangan, kekalan materi dan kekekalan panjang yang dimiliki peserta didik usia 7-8 tahun.

\section{METODE PENELITIAN}

Penelitian ini adalah penelitian kuantitatif dengan pendekatan deskriptif kualitatif yaitu mendeskripsikan kesesuain teori perkembangan kognitif Piaget dengan kemampuan memahami hukum kekekakalan bilangan, kekekalan materi dan kekekalan panjang peserta didik kelas I dan II. Populasi dalam penelitian ini adalah seluruh peserta didik kelas I dan II sebanyak 52 peserta didik. Sampel penelitian diambil secara acak sebanyak 14 peserta didik.

Instrumen yang digunakan dalam penelitian ini adalah instrument tes tentang hukum kekekalan bilangan, kekekalan materi dan kekekalan panjang yang dilengkapi dengan instrument non tes yaitu wawancara yang dipadukan dengan percobaan sederhana. Tes tersebut berupa pertanyaan-pertanyaan untuk mengetahui seberapa jauh pemahaman anak mengenai konsep hukum kekekalan bilangan, kekekalan materi dan kekekalan panjang. Pertanyaan berupa "apakah sama atau tidak ...?" dan 
"manakah yang lebih ...?" diajukan untuk beberapa kondisi benda dan materi selama berlangsungnya tes konservasi. Selanjutnya wawancara dan percobaan sederhana dilakukan untuk mengetahui lebih dalam mengenai alasan anak menjawab setiap pertanyaan yang diberikan. Peneliti melakukan wawancara kepada setiap peserta didik yang menjadi sampel penelitian. Secara keseluruhan, setiap sampel diwawancara secara personal untuk setiap jenis konservasi. Objek yang digunakan untuk tes konservasi adalah uang logam, air dan tali. Secara umum, tes dan wawancara dengan percobaan sederhana tentang hukum kekekalan bilagan, kekekalan materi dan kekekalan panjang dengan objek uang logam, air dan tali mengikuti 2 tahapan. Pertama, kedua objek ditempatkan dalam kondisi sama persis dan kedua dilakukan manipulasi pada satu objek dan membiarkan objek lainnya seperti keadaan awal.

Hasil tes memahami hukum kekekalan bilangan, materi dan panjang terhadap peseta didik kelas I dan II ini dianalisis dan digolongkan ke dalam 4 kategori, yakni sangat baik, baik, cukup baik dan tidak baik. Penggolongan ini berdasarkan jawaban sampel dalam menjawab setiap tes. Selanjutnya, peneliti juga melakukan wawancara yang dipadukan dengan percobaan sederhana untuk mengetahui lebih dalam mengenai kemampuan peserta didik dalam memahami hukum kekekalan ini. Hasil wawancara dan percobaan sederhana ini di analisis dengan melakukan tahapan reduksi data, penyajian data dan verifikasi data.

\section{HASIL DAN PEMBAHASAN}

Penelitian ini bertujuan untuk mengetahui kesesuaian antara teori perkembangan kognitif yang dikemukakan oleh Jean Piaget dengan perkembangan kognitif peserta didik kelas I dan II dalam hal memahami hukum kekekalan yang difokuskan pada hukum kekekalan bilangan, hukum kekekalan materi dan hukum kekekalan panjang. Berdasarkan penelitian yang telah dilakukan terhadap 14 peserta didik yang meliputi kegiatan pemberian tes, wawancara dan percobaan sederhana, penelitian tersebut memperoleh hasil penelitian sebagai berikut.

Nilai dari hasil tes peserta didik tersebut dibagi menjadi 4 tingkat kemampuan memahami hukum kekekalan bilangan, kekekalan materi dan kekekalan panjang yaitu kategori sangat baik, baik, cukup baik dan tidak baik. Adapun untuk nilai dari masingmasing peserta didik disajikan dalam Tabel 3 :

Tabel 3. Tes Peserta Didik Kelas I dan II Tahun Ajaran 2019/2020 Tentang Hukum Kekekalan Bilangan, Kekekalan Materi Dan Kekekalan Panjang

\begin{tabular}{ccccc}
\hline No & Nama & Nilai & Persentase & Tingkat Pemahaman \\
\hline 1 & S01 & 30 & $50 \%$ & Tidak Baik \\
2 & S02 & 30 & $50 \%$ & Tidak Baik \\
3 & S03 & 40 & $67 \%$ & Cukup Baik \\
4 & S04 & 30 & $50 \%$ & Tidak Baik \\
5 & S05 & 30 & $50 \%$ & Tidak Baik \\
6 & S06 & 30 & $50 \%$ & Tidak Baik \\
7 & S07 & 55 & $92 \%$ & Sangat Baik \\
8 & S08 & 50 & $83 \%$ & Baik
\end{tabular}




\begin{tabular}{ccccc}
9 & S09 & 60 & $100 \%$ & Sangat Baik \\
10 & S10 & 60 & $100 \%$ & Sangat Baik \\
11 & S11 & 30 & $50 \%$ & Tidak Baik \\
12 & S12 & 30 & $50 \%$ & Tidak Baik \\
13 & S13 & 55 & $92 \%$ & Sangat Baik \\
14 & S14 & 40 & $67 \%$ & Cukup Baik \\
\hline
\end{tabular}

Berdasarkan Tabel 3 nilai tes yang diperoleh oleh peserta didik, diketahui bahwa ada 4 peserta didik yang mendapat kategori sangat baik, 1 peserta didik termasuk kategori baik, 2 peserta didik termasuk kategori cukup baik dan ada 7 peserta didik yang termasuk kategori tidak baik. Sehingga dapat disimpulkan bahwa ada 50\% sampel dari peserta didik telah memahami konsep hukum kekekalan bilangan, kekekalan materi dan kekekalan panjang berdasarkan nilai tes. Berikut hasil wawancara dan percobaan sederhana.

\subsection{Hukum Kekekalan Bilangan}

Sebelum melaksanakan wawancara dan percobaan sederhana tentang hukum kekekalan bilangan, pertama-tama peneliti menanyakan nama, kelas dan menguji apakah peserta didik tersebut sudah mampu membilang bilangan 1 sampai dengan 10 . Berdasarkan hasil wawancara diketahui bahwa semua sampel sudah dapat membilang bilangan 1 sampai dengan 50. Hal tersebut penting untuk dilakukan karena apabila sampel belum dapat membilang minimal 10 bilangan pertama, maka kegiatan wawancara dan percobaan sederhana tidak dapat dilakukan lebih lanjut. Setelah itu, peneliti meminta sampel untuk menghitung banyak uang logam yang disediakan. Kemudian peneliti membagi uang logam menjadi dua tumpukan dengan banyak yang sama yaitu 10 koin. Peneliti kemudian menanyakan "apakah kedua tumpukan uang logam tersebut banyaknya sama?". Semua sampel menjawab "sama" pada kondisi logam di ditumpukan menjadi dua sama banyak. Setelah itu, peneliti melanjutkan penelitian dengan mengubah posisi salah satu tumpukan uang logam menjadi berjejer dan menanyakan kembali "apakah uang logam tersebut banyaknya sama dan berikan alasan”. Untuk pertanyaan ini, 13 dari 14 sampel menjawab bahwa banyak uang logam tersebut sama. Alasan S01 adalah "kakak tidak menambahkan uangnya lagi dan kakak tidak mengambilnya". S02 memberikan alasan "Karena banyaknya tetap sama kak". S03 alasannya adalah "Karena banyak uang logamnya masih sama sama 10 kak". S04 alasannya adalah "Karena banyaknya tetap 10". S05 alasannya adalah "Karena kakak hanya mengubah posisinya". S06 alasannya adalah "Karena banyaknya sama-sama 10 kak". S07 alasannya adalah "Karena uangnya tetap sama sama 10 kak", jawaban yang diberikan ini sejalan dengan jawaban yang diberikan saat menjawab soal tes. S08 alasannya adalah "Karena tidak ditambahkan ataupun dikurangi banyak uangnya". S09 alasannya adalah "Karena uangnya tidak kakak tambahkan ataupun diambil". S10 alasannya adalah "Karena kakak tidak menambahkan ataupun mengurangi banyak uangnya". S11 alasannya adalah "Karena tidak ditambahkan ataupun dikurangi uangnya". S13 alasannya adalah "Karena tidak ditambahkan ataupun dikurangi uangnya". S14 alasannya adalah "Karena tidak ditambahkan ataupun dikurangi". 
Berdasarkan jawaban dan alasannya yang diberikan, dapat diketahui bahwa peserta didik tersebut sudah memahami konsep hukum kekekalan bilangan. Hal ini sesuai dengan teori perkembangan kognitif yang dikemukakan oleh Jean Piaget (dalam Suratno, Utami dan Hamid, 2015) bahwa anak yang telah memahami kekekalan bilangan, maka anak akan mengerti bahwa banyaknya benda-benda itu akan tetap walaupun letaknya berbeda beda selama benda tersebut tidak ditambahkan ataupun dikurangi. Teori tentang hukum kekekalan bilangan ini sesuai dengan alasan yang diberikan oleh S01, S08,S09, S10, S11, S13 dan S14. Dalam buku yang berbeda mengatakan bahwa peserta didik telah memahami hukum kekekalan bilangan bila ia mengerti bahwa banyaknya benda-benda itu akan tetap sama walaupun letaknya berbeda-beda (Santrock, 2007). Hal ini sesuai dengan alasannya yang diberikan oleh S05. Piaget juga menyatakan tentang hukum kekekalan bilangan (dalam Astuti, 2015) bahwa hukum kekekalan/ konservasi bilangan sudah ada dalam diri peserta didikditandai dengan adanya persepsi bahwa jumlah benda tertentu tidak berubah jumlahnya jika ditempatkan dengan berbagai cara. Hal ini sesuai dengan jawaban yang diberikan oleh S02, S03, S04, S06 dan S07.

Adapun berdasarkan hasil penelitian diketahui juga bahwa ada satu sampel yang belum memahami hukum kekekalan bilangan yaitu S12. Hal ini diketahui berdasarkan hasil wawancara diketahui bahwa S12 memberikan alas an yang tidak sesuai dengan teori perkembangan kognitif yang dikemukakan oleh Piaget. S12 mengatakan bahwa uang yang berjejerlah yang lebih banyak dengan alas an "Karena logamnya keliatan lebih banyak". Hasil penelitian ini sejalan dengan penelitian yang telah dilakukan sebelumnya oleh Funny (2014) yang menunjukkan bahwa kemampuan konservasi anak umumnya masih rendah dan masih terdapat kekeliruan saat menentukan kekekalan suatu bilangan.

\subsection{Hukum Kekekalan Materi}

Dalam melakukan wawancara dan percobaan sederhana tentang hukum kekekalan materi, peneliti menyediakan 2 gelas yang berukuran sama, mangkok dan air untuk melakukan kegiatan tersebut. Pertama-tama, peneliti menuangkan air dengan isi sama banyak di kedua gelas yang berukuran sama, kemudian menanyakan kepada sampel "apakah banyak isi air dikedua gelas sama?". Semua sampel menjawab "sama" untuk pertanyaan ini. Selanjutnya peneliti memindahkan air dari salah satu gelas kedalam mangkok dan membiarkan air dalam gelas yang satunya. Kemudian peneliti menanyakan "apakah isi air dari gelas dan mangkok sama?". Dari 14 sampel yang diteliti, ada 9 peserta didik yang memberikan jawaban yang sesuai dengan teori perkembangan kognitif Piaget tentang hukum kekekalan materi yaitu S01, S02, S04, S06, S07, S08, S09, S10 dan S13.

S01 memberikan alas an "Karena kakak hanya menyalin tempatnya". S02 memberikan alas an "Karena kakak hanya memindahkan tempat airnya". S04 memberikan alas an "Karena kakak tidak menambahkan airnya dan tidak menguranginya juga" S06 alasannya adalah "Karena kakak tidak menambahkan 
airnya". S07 alasannya adalah "Karena airnya hanya dipindahkan tempatnya". S08 alasannya adalah "Karena air tidak ditambahkan atau dikurangi banyaknya". S09 alasannya adalah "Karena kakak tidak menambahkan atau mengurangi airnya". S10 alasannya adalah "Karena kakak hanya memindah tempat airnya". S13 alasannya adalah "Karena airnya tidak ditambahkan atau dikurangkan". Berdasarkan alas an yang diberikan ini dapat diketahui bahwa ke Sembilan sampel tersebut sudah memahami hukum kekekalan materi. Hal ini sesuai dengan teori perkembangan kognitif yang dikemukakan oleh Jean Piaget bahwa anak yang memahami hukum kekekalan materi atau zat akan mengatakan bahwa materi atau zat akan tetap sama banyaknya meskipun diubah bentuknya atau dipindahkan tempatnya. Sedangkan anak yang belum memahami hukum kekekalan materi akan mengatakan, bahwa air pada dua mangkok yang berbeda besarnya menjadi tidak sama, meskipun anak tersebut tahu bahwa air tersebut dituangkan dari dua bejana yang sama besar dan sama banyaknya (Ramlah, 2015). Dalam (Astuti, 2015) juga dijelaskan bahwa hukum kekekalan substansi/ konservasi substansi sudah ada pada diri peserta didikditandai dengan adanya persepsi bahwa benda-benda itu tidak berubah walaupun bentuk wadahnya berubah-ubah. Hal ini sesuai dengan jawaban yang diberikan oleh S01, S02, S07 dan S10 tentang hukum kekekalan materi. Dalam buku psikologi pendidikan dijelaskan bahwa peserta didik meyakini bahwa jumlah materi tetaplah sama jika tidak ada yang ditambahkan atau dikurangkan, kendatipun substansinya (penampakannya) diubah atau disusun ulang (Santrock, 2007). Dalam (Suparno, 2001) dijelaskan juga bahwa anak yang sudah berada dalam tahap operasi konkret mengetahui bahwa meskipun tinggi air tidak sama, volumenya akan tetap sama. Baginya air tidak akan berubah selama air tersebut tidak ditambahkan atau dikurangkan. Teori tentang hukum kekekalan materi menurut Jean Piaget ini sesuai jawaban yang diberikan oleh S04, S06, S08, S09 dan S13.

Berdasarkan hasil penelitian di ketahui bahwa ada lima sampel yang belum memahami hukum kekekalan materi yaitu S03, S05, S11, S12 dan S14. Jawaban yang diberikan oleh kelima sampel ini belum sesuai dengan teori perkembagan kognitif Jean Piaget. S03 memberikan alas an "Karena kakak memindahkan airnya ke mangkok yang lebih besar". S05 alasannya adalah "Karena mangkok lebih besar dari gelas". S11 alasannya adalah "air yang dimangkok lebih banyak karena airnya kelihatan lebih banyak". S12 alasannya adalah "Karena lebih banyak dari gelas yang kecil". S14 alasannya adalah "Karena ukuran mangkoknya lebih besar dari gelas". Berdasarkan alasan yang diberikan ini, diketahui bahwa S03, S05, S11, S12 dan S14 belum memahami tentang hukum kekekalan materi. Hasil penelian ini sesuai dengan penelitian yang dilakukan oleh Ramlah (2015) bahwa terdapat anak yang sudah memasuki tahap berpikir konkret tetapi belum mampu mememahami konsep dari hukum kekekalan materi tersebut. 


\subsection{Hukum Kekekalan Panjang}

Untuk melakukan wawancara dan percobaan sederhana terhadap hukum kekekalan panjang, peneliti menyediakan seutas tali dan gunting. Peneliti memulai wawancara dan percobaan sederhana dengan memotong tali tersebut menjadi dua bagian dengan panjang yang sama, kemudian peneliti menanyakan kepada sampel "apakah panjang kedua tali tersebut sama?". Semua sampel menjawab "sama”. Setelah itu, peneliti merubah posisi salah satu tali menjadi di gulung dan satunya lagi dibiarkan memanjang, kemudian peneliti bertanya "apakah kedua tali tersebut panjangnya sama dan apa alasannya?”. Berdasarkan pertanyaan tersebut 9 dari 14 sampel memberikan jawaban dan alas an yang sesuai dengan teori perkembangan kognitif Jean Piaget tentang hukum kekekalan panjang yaitu S03, S04, S06, S07, S08, S09, S10, S13 dan S14. S03 memberikan alas an "Karena kakak tidak memotong talinya". S04 alasannya adalah "Karena kakak tidak memotong talinya lagi". S06 alasannya adalah "Karena kakak hanya menggulung talinya". S07 alasannya adalah "Karena talinya hanya diubah posisinya". S08 alasannya adalah "Karena tali tidak ditambahkan atau dikurangi". S09 alasannya adalah "Karena kakak hanya merubah bentuk tali". S10 alasannya adalah "Karena tali tidak dipotong lagi". S13 alasannya adalah "Karena kakak tidak memotong talinya lagi". S14 alasannya adalah "Karena talinya hanya digulung tidak dipotong lagi".

Berdasarkan jawaban yang diberikan ini dapat diketahui bahwa peserta didik sudah memahami konsep hukum kekekalan panjang sesuai dengan teori perkembangan kognitif yang dikemukakan oleh Jean Piaget. Menurut Jean Piaget Piaget (dalam Hindun dan Russefendi: 2018) bahwa anak yang telah memahami konsep kekekalan panjang akan mengatakan bahwa panjang tali akan tetap meskipun tali itu dilengkungkan. Dalam Astuti (2015) tentang hukum kekekalan panjang Piaget juga dijelaskan bahwa panjang suatu benda tidak berubah walaupun ditempatkan dengan berbagai cara, dibentangkan, digulung, dan sebagainya. Hal ini sesuai dengan jawaban yang diberikan oleh S06, S07 S09 dan S14. Penjelasan tentang hukum kekekalan panjang ini juga dijelaskan oleh Piaget (dalam Russefendi, 2006) bahwa Anak yang memahami hukum kekekalan panjang akan mengatakan bahwa panjang suatu benda akan tetap sama meskipun diubah bentuknya tanpa menambah atau mengurangi benda tersebut. Hal ini sesuai dengan jawaban yang diberikan oleh S03, S04, S08, S10 dan S13. Hal ini juga sejalan dengan penelitian yang dilakukan oleh Jean Piaget yang menggunakan tongkat yang di potong-potong serta dibengkokkan. Dimana Jean piaget mengatakan bahwa anak yang telah berada dalam tahap berpikir konkret ini akan dapat menyatakan bahwa panjangnya akan tetap sama (Suparno, Paul: 2001).

Berdasarkan hasil penelitian juga diketahui bahwa ada sampel yang belum memahami hukum kekekalan panjang yaitu S01, S02, S05, S11 dan S12. Hal ini diketahui dari alas an yang diberikan tidak sesuai dengan teori perkembangan kognitif yang dikemukakan oleh Jean Piaget tentang hukum kekekalan panjang. Hasil penelitian ini sejalan dengan penelitian yang dilakukan oleh Al-Haddad (2015) yang 
menyatakan bahwa terdapat anak yang sudah sesuai dengan usianya berada dalam tahap berpikir konkret ternyata belum memahami konsep kekekalan panjang.

\section{SIMPULAN}

Berdasarkan data hasil penelitian dan pembahasan, dapat disimpulkan bahwa:

1. Dari 14 sampel yang diteliti, diketahui bahwa ada 13 peserta didik sudah memahami konsep kekekalan bilangan dan sesuai dengan perkembangan kognitif Jean Piaget namun masih ada 1 peserta didik yang belum mampu memahami konsep kekekalan bilangan tersebut walaupun usianya sudah memasuki tahap berpikir konkret namun tahap kognitifnya belum sesuai dengan teori perkembangan kognitif Jean Piaget.

2. Dari 14 sampel yang telah diteliti diketahui ada 9 peserta didik berusia 7-8 tahun yang sudah memahami konsep kekekalan materi dan sesuai dengan teori perkembangan kognitif Piaget namun dari hasil penelitian diketahui masih ada 5 peserta didik berusia 7-8 tahun yang belum memahami konsep hukum kekekalan materi tersebut. Sehingga dapat dikatakan bahwa perkembangan kognitif mereka belum sesuai dengan perkembangan kognitif Jean Piaget dalam memahami hukum kekekalan.

3. Dari 14 sampel yang diteliti diketahui bahwa ada 9 peserta didik usia 7-8 tahun sudah memahami hukum kekekalan panjang dan ada 5 peserta didik yang belum memahami konsep kekekalan panjang. Sehingga dapat dikatakan perkembangan kognitif mereka belum sesuai dengan perkembangan kognitif yang dikemukakan oleh Jean Piaget.

\section{REFERENSI}

Aini, I.N dan Hidayati, N. 2017. Tahap Perkembangan Kognitif Matematika Siswa Smp Kelas VII Berdasarkan Teori Piaget Ditinjau Dari Perbedaan Jenis Kelamin. JPPM Vol 10(2), hal: 25-30.

Alhaddad, I. 2012. Penerapan Teori Perkembangan Mental Piaget Pada Konsep Kekekalan Panjang. Jurnal ilmiah program studi matematika STKIP Siliwangi Bandung Vol 1(1), hal: 31- 44.

Astuti, A.G. 2015. Kemampuan Berpikir Logis Bertipe Kecerdasan Logis Matematis Terkait dengan Konservasi Bagi Anak Berusia 7-8 Tahun. Jurnal Horizon Pendidikan Vol 10(2), hal: 221-230.

Depdiknas. 2004. Standar Kompetensi Kurikulum 2004. Jakarta: Departemen Pendidikan Naisonal.

Funny, R. A. 2014. Students' Initial Understanding Of The Concept Of Conservation Of Area. Indonesian Mathematical Society Journal on Mathematics Education Vol 5(1), hal: 57-65.

Hidayati, K. 2012. Pembelajaran Matematika Usia SD/MI Menurut Teori Belajar Piaget. Jurnal Cendekia Vol 10(2), hal: 291-308.

Hindun, S dan Ruseffendi, E.H. 2018. Apakah Teori Perkembangan Kognitif Piaget Berlaku di Indonesia?. UNINUS Journal Published Vol. 3(2), hal: 99-103

Mufarizuddin. 2017. Peningkatan Hasil Belajar Matematika Siswa SD Kelas V Melalui Model Pembelajaran Kooperatif Tipe STAD. Jurnal Pelangi. Vol 9(2), hal: $113-122$ 
Ormrod, J.E. 2008. Psikologi Pendidikan: Membantu Siswa Tumbuh dan Berkembang. Edisi keenam. Jakarta: Erlangga.

Orton, A. 2004. Learning Mathematics: Issue, Theory and Classroom Practice ( $3^{\text {rd }}$ ed). London: Continuum.

Ramlah. 2015. Penerapan Teori Perkembangan Mental Piaget Tahap Operasional Konkret Pada Hukum Kekekalan Materi. Jurnal pendidikan UNSIKA Vol 3(2), hal: 221-230

Riyatuljannah, T dan Suyadi. 2020. Analisis Perkembangan Kognitif Siswa Pada Pemahaman Konsep Matematika Kelas V SDN Maguwoharjo 1 Yogyakarta. Jurnal Pendidikan Dasar Vol 12(1), hal: 48-54.

Santrok, J.W. 2007. Psikologi Pendidikan. Edisi Kedua. Jakarta: Prenadamedia Group.

Suparno, P. 2001. Teori Perkembangan Kognitif Jean Piaget. Yogyakarta: Kanisus.

Suratno, J., Utami, N.W., dan Hamid, H. 2015. Konsep Kekekalan Bilangan dan Substansi. Jurnal Matematika dan Pendidikan Matematika Vol 4(1), hal: 42-56. 